\title{
ZAŠTITA DJEČJIH PRAVA U HUMANITARNIM AKCIJAMA S OSVRTOM NA AFRIČKE ZEMLJE'
}

\section{Leali Osmančević}

PRETHODNO PRIOPĆENJE / DOI: 10.20901/ms.9.18.3 / PRIMLJENO: 09.06.2018.

SAŽETAK Rad se bavi ulogom medija u društvu te važnošću profesionalnoga izvještavanja i odgoja za medije, posebice u kontekstu djece i zaštite dječjih prava. Humanitarne akcije namijenjene djeci česta su tema u medijima, no paradoks je da su djeca i njihove potrebe, kao i njihova prava, posebice pravo na privatnost i izražavanje mišljenja, marginalizirani. Na javnost se često apelira putem medija kroz humanitarne akcije te se izazivanjem snažnih i krajnjih emocija potiče na pomoć. Nerijetko je baš u takvim slučajevima dijete kao glavni subjekt humanitarne akcije ogoljeno te je njegova intima dostupna svima, često pod argumentom da je sve što je u interesu javnosti opravdano. Cilj je rada, pregledom dosadašnjih spoznaja, ukazati na važnost zaštite djece kao najosjetljivije skupine društva i dječjih prava u prosocijalnim sadržajima kao što su humanitarne akcije. Rad će dati i pregled stanja prikazivanja humanitarnih akcija za pomoć djeci u afričkim zemljama.

KLJUČNE RIJEČI

DJECA, MEDIJI, DJEČJA PRAVA, HUMANITARNE AKCIJE, DJEČJI DOMOVI, ODGOJ ZA MEDIJE

Bilješka o autorici

Leali Osmančević :: Hrvatsko katoličko sveučilište, Zagreb, Hrvatska :: leali.osmancevic@unicath.hr

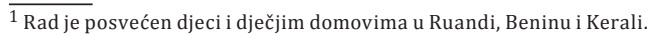




\section{UVOD}

Nedvojbeno je da mediji više ne podrazumijevaju samo klasičan ili jednosmjeran prijenos informacija, već komunikacijske procese izvan okvira ustaljenih društvenih normi. Naime, novi mediji imaju sve veći utjecaj na prirodu interakcije, bilo da je riječ o komunikaciji licem u lice, o komunikaciji posredovanoj putem računala ili političkoj komunikaciji. Najveća se pozornost pridaje internetu i njegovim javnim aspektima interakcije korisnika. Dosadašnja je komunikacijska tehnologija pod utjecajem digitalizacije dobila niz novih mogućnosti korištenja i distribucije informacija. Razvoj novih medija početkom 21. stoljeća doveo je i do napretka na području demokracije, ljudskih prava i cjelokupne komunikacijske etike (v. McQuail, 2010: 157). Unatoč brojnim promjenama koje su novi mediji donijeli bitno je naglasiti kako oni nisu zamjena klasičnim medijima, već njihova dopuna.

Mediji svojim djelovanjem daju glas javnosti i mogu biti vrlo moćan alat, bilo da je riječ o pozitivnim ili negativnim sadržajima o kojima izvještavaju, te na taj način izravno utječu i na bitne sastavnice društva kao što su demokracija, sloboda, mir i ljudska prava (Oyero, 2010: 28). Zbog toga novinari i svi medijski djelatnici trebaju u svakom trenutku biti svjesni svoje uloge u društvu i važnosti same profesije, kao i odgovornosti prema svojoj profesiji, samima sebi i svojoj publici. Brojna postojeća etička načela novinarske profesije usmjeravaju i određuju stupanj odgovornosti novinara u obavljanju novinarsko posla. Sama etika, pa tako i ona medijska, usko je i izravno povezana s novinarskom profesijom (Poler, 1997 prema Majstorović, 2017: 57). Prenošenje istine, objektivno izvještavanje i odgovornost neki su od temeljnih zahtjeva koje društvo očekuje od novinarske profesije (Labaš i Vizler, 2005: 294). Također, vjerodostojnost novinarskog izvještavanja, pa tako i medija općenito, uvelike ovisi o slijeđenju etičkih načela novinarske profesije te svaki oblik novinarstva koji nije usklađen s tim načelima više ne predstavlja novinarstvo kao odgovornu profesiju (Majstorović, 2017: 57).

Također, nužno je naglasiti i ulogu medija u konstruiranju društvene stvarnosti. Takav je proces kompleksan, ponajprije zato što uključuje niz čimbenika poput vlasničke strukture medija, dostupnosti tehnologije u medijskim kućama, načina i izvora financiranja medija i sl. Medijski tekst koji nastane uslijed svih tih čimbenika tek je krajnji proizvod koji je uvjetovan ne samo novinarom kao autorom nego i mnogobrojnim višeslojnim elementima (Hromadžić, 2014: 24-27). Postoji mnoštvo teorija i pristupa u objašnjavanju uključenosti medija u promjene, u utjecaj na stvarnost te u kreiranje stvarnosti, no samo proučavanje tzv. medijske konstrukcije stvarnosti temelji se na dvije škole, školi procesa (engl. process school) i semiotičkoj školi (engl. semiotic shool) (Hromadžić, 2014: 24). Obje škole bave se proučavanjem komunikacije, no razlikuju se u pristupima. Škola procesa proučava pojedinačne segmente komunikacije, nazivajući ih aktivnostima, te se pri njihovu definiranju služi društvenim znanostima, posebice psihologijom i sociologijom. Škola procesa poruku definira kao nešto što je preneseno procesom komunikacije. Semiotička je škola s druge strane usmjerena na ishode i učinke komunikacije, uzimajući u obzir lingvistiku i umjetnost te kulturalne studije. Medijske poruke povezuje sa znakovima, simbolima i kodovima te njihovo značenje povezuje s publikom, odnosno s primateljima informacije bez kojih poruka kao takva ne može imati smisao (Fiske, 2010: 2-3). Na oblikovanje medijski 
konstruirane stvarnosti utječu čimbenici iz različitih područja, kao što su javne politike, interesi političkih i ekonomskih elita, kultura i različiti društveni procesi, te su upravo oni temelj medijskih narativa koje javnost, odnosno publika, čita, sluša i gleda. No, proces konstrukcije medijske stvarnosti uvjetovan je i nizom čimbenika koji se tiču samih medija i načina na koji proizvode sadržaje, pa tako i humanitarne akcije, a ponajprije je riječ o pitanju vlasničke strukture i financiranja medija, ali i tehnoloških promjena. Zbog toga su različiti medijski narativi, u koje ubrajamo i humanitarne akcije, tek konačni proizvod koji nastoji udovoljiti svim spomenutim čimbenicima (Hromadžić, 2014: 27).

Humanitarne akcije u medijima, posebice one namijenjene pomoći djeci kao jednoj od najosjetljivijih skupina društva i medijskih publika, česta su pojava u medijskome prostoru, no jedan od glavnih izazova koji se javlja jest odnos i sadržaj same humanitarne akcije s medijskim kućama i djelatnicima zbog nerijetko nedovoljno profesionalnog pristupa između poticanja javnosti na pomoć i istovremenog poštivanja etičkih profesionalnih načela s ciljem zaštite temeljnih ljudskih prava, a u ovome kontekstu dječjih (Minear i sur., 1996: 86).

Cilj ovoga rada jest istaknuti ulogu i važnost profesionalnog medijskog izvještavanja u zaštiti djece i dječjih prava te dati pregled izvještavanja o humanitarnim akcijama i njihovim temeljnim postulatima, s posebnim osvrtom na stanje u nekim afričkim zemljama, posebice zbog učestalosti humanitarnih akcijama namijenjenih različitim skupinama djece, nerijetko djece iz dječjih domova, te njihova prikaza u zapadnome dijelu svijeta. Rad će na kraju donijeti i smjernice proizašle iz korištene recentne i relevantne literature koje mogu doprinijeti profesionalnijem medijskom izvještavanju u Hrvatskoj o humanitarnim akcijama, posebice onima usmjerenima na afričke zemlje.

\section{ULOGA I VAŽNOST PROFESIONALNOG MEDIJSKOG IZVJEŠTAVANJA U PROMOCIJI I ZAŠTITI DJECE I DJEČJIH PRAVA}

Sloboda i odgovornost novinara, kao i svih medijskih djelatnika, nužni su kako bi novinari i ostali medijski djelatnici mogli djelovati i utjecati na cijelo društvo. No, u kontekstu medija i društva te medijske etike neizostavno je spomenuti i odgovornost publike, odnosno primatelja medijskih sadržaja. Komunikolog koji se posebno bavio upravo tim pitanjem jest Cees J. Hamelink koji je naglašavao da mediji sami po sebi ne mogu promijeniti društvo ili utjecati na publiku jednosmjerno, već da i publika, odnosno primatelji, treba biti jednako etički odgovorna kao što se očekuje i od samih medija (v. Labaš i Vizler, 2005: 282). Uloga i odgovornost publike u čitanju različitih medijskih tekstova velika je i neizostavna. Sposobnost analize i interpretacije medijskih poruka ovisi o načinu korištenja medija, kao i o vlastitim stavovima i vrijednostima. Ispreplitanje medijskog narativa i konstruirane stvarnosti s već stečenim iskustvenim i vrijednosnim sudovima svakog pojedinca rezultira dekodiranjem i interpretacijom medijskih poruka (Hromadžić, 2014: 147148). Pri čitanju, gledanju ili slušanju različitih medijskih sadržaja publika ima određena očekivanja koja usklađuje s određenim obrascima ponašanja. Kako bi što jasnije shvatila bit neke medijske poruke i sadržaja, publika pri recepciji selektira najvažnije informacije. 
Međutim, do promjene može doći ukoliko su pri recepciji sadržaja prisutne i druge aktivnosti koje od primatelja zahtijevaju pažnju i koje pritom mogu utjecati na razumijevanje medijske poruke. Kada je riječ o očekivanjima publike, recepcija nekog medijskog sadržaja, posebice onog televizijskog, ne mora nužno značiti da će primatelji kritički analizirati taj sadržaj (Silverblatt i sur., 2014: 8).

Kada je riječ o djeci kao najosjetljivijoj publici, odnosno primateljima svih medijskih sadržaja, te o zaštiti, i promociji njihovih prava, nužno je ponajprije navesti da svako medijsko izvještavanje koje uključuje djecu na bilo koji način utječe na percepciju djece o samima sebi, potom na percepciju njihovih vršnjaka o kojima se izvještava te naposlijetku na percepciju čitavoga društva o djeci kao zasebnoj društvenoj skupini. Nepotpun i nedovoljno profesionalan pristup izvještavanju o djeci u medijima može dovesti do niza posljedica, a posebice do generalizacije određene skupine djece na temelju jednog izdvojenog slučaja koji je prikazan u medijima (Flego, 2011: 138), bilo da je riječ o nekom tragičnom događaju ili humanitarnoj akciji, s obzirom na to da u oba slučaja dječja prava mogu biti nedovoljno zaštićena. Razlog velikog utjecaja medija na dječje samopoimanje i poimanje stvarnosti jest neprestani razvoj dječjih kognitivnih, društvenih i emocionalnih obilježja tijekom njihova odrastanja. Sva ta obilježja dio su dječjeg identiteta i osobnosti te se razvijaju u skladu s brojnim faktorima koje, uz djetetovo okruženje, obitelj, kulturu i običaje, čine i mediji, odnosno medijski sadržaji kojima su djeca izložena (Lemish, 2015: 42). Način na koji će medijski sadržaji utjecati na dijete i njegov daljnji razvoj objašnjava i razvojna psihologija, prema kojoj djeca pridaju značenje medijima sukladno svojoj dobi i dotadašnjem iskustvu te u skladu sa svim tim čimbenicima svoje ponašanje, mišljenje, stavove i vrijednosti manifestiraju u svoju svakodnevicu i stvarnost koja ih okružuje (Valkenburg, 2004; Van Evra, 2004 prema Lemish, 2015: 42). Psiholog Albert Bandura pojasnio je i kroz teoriju socijalnog učenja kako masovni mediji imaju značajnu ulogu u oblikovanju i percepciji dječjih vrijednosti ponajviše zbog visokog stupnja persuazije, odnosno tehnike uvjeravanja koje medijski sadržaji imaju te uz pomoć koje i konstruiraju dječju stvarnost (Bandura, 2001 prema Calvert i Wilson, 2009: 75). Djeca na određeni način odabiru, tumače i koriste informacije koje su dobili te naposlijetku o njima, svjesno ili nesvjesno, donose sud ili odluku, odnosno socijalnu spoznaju. Automatska mišljenja i ponašanja koja djeca mogu usvojiti nisu svjesna i namjerna te djeca u njih ne moraju ulagati nikakav napor (Aronson i sur., 2005: 58-59). Mediji utječu i na dječje ponašanje, stavove i vrijednosti te kroz različite sadržaje i korisničke prakse konstruiraju njihovu stvarnost. Ukoliko se sve navedeno stavi u kontekst humanitarne akcije namijenjene djeci vrlo je jasno vidljivo koliko nedovoljno profesionalno i nedovoljno etično prikazana humanitarna akcija, kao i svi njezini akteri, može nedvojbeno trajno utjecati na djecu i njihov stav prema njima samima, kao i na stav odraslih prema djeci kao osjetljivoj društvenoj skupini.

U Hrvatskoj su se brojni znanstvenici u svojim istraživanjima bavili upravo tom temom, no većina rezultata istraživanja pokazala je i ujedno ukazala čitavom društvu na negativan trend medijskog izvještavanja o djeci bez djece kao izvora informacija (Ciboci i sur., 2011), potom na kršenje temeljnih dječjih prava, poput prava na privatnost (Ciboci i sur., 2011; Vlainić, 2012; Ciboci i Osmančević, 2014), te na općeniti nedostatak pozitivnih tema o djeci, poput izvještavanja o dječjim uspjesima (Ciboci i Osmančević, 2017: 100) kroz koje se pro- 
moviraju i istovremeno i štite njihova prava. Pretjerano izlaganje djetetove intime i kršenje njihovih prava može se prevenirati i nadomjestiti upravo profesionalnim pristupom medijskom izvještavanju te svaku temu, od negativne do pozitivne, kvalitetno predstaviti javnosti, odnosno svojoj publici. No, često je upravo medijska želja za senzacionalizmom, pa čak i u humanitarnim akcijama, upravo ta koja nadilazi temelje novinarske profesije, u koje se ubraja i zaštita dječjih prava. lako senzacionalistički pristup izvještavanju o djeci javnost zainteresira tek nakratko, posljedice su s druge strane za samu djecu puno dugotrajnije (Vilović, 2007: 32). U zaključnom razmatranju ovog uvodnog poglavlja valja napomenuti i da djeca, upravo zbog nedovoljnog poštivanja dječjih prava u medijima, nisu ni sama dovoljno upoznata sa svim svojim temeljnim pravima te ih ne znaju u cijelosti definirati ili navesti (Ciboci i Osmančević, 2017: 96).

\section{ZAŠTITA DJEČJIH PRAVA U HUMANITARNIM AKCIJAMA}

Humanitarne akcije najčešće su usmjerene spašavanju nečijeg života, bilo da je riječ o prirodnoj katastrofi, bolesti, siromaštvu ili gladi. Upravo su humanitarne akcije te koje su postale ključni medijski sadržaji i usko se vezuju uz siromašne zemlje, posebice kada je riječ o djeci, a potom i uz ratove ili bilo koji oblik sukoba unutar neke zemlje (Hilhorst i Jansen, 2012: 892). One se također vezuju i uz bilo koji oblik tragičnog ili nesretnog događaja neovisno o njegovu razmjeru te stanjima pojedinaca, primjerice organiziranje humanitarne akcije za pomoć jednom bolesnom djetetu unutar neke lokalne zajednice ili skupine pojedinaca ili organiziranje pomoći za određenu skupinu koja živi u zasebnom objektu uslijed životnih prilika, primjerice u dječjem domu, domu za starije i nemoćne osobe, domu za beskućnike i sl. Jedna od najvećih dvojbi u prezentiranju i izvještavanju o nekoj humanitarnoj akciji jest pronaći ispravan, etičan i profesionalan način kroz koji će se sustavno i istovremeno štititi dječja prava i pomoći im jer su u potrebi (Weiss, 2018: 2).

Svakako da bi cilj svake humanitarne akcije namijenjene djeci trebao biti vezan uz otvaranje aktualnih pitanja, pronalazak rješenja za određeni problem, poticanje javnosti na sudjelovanje u akcijama o važnim društvenim temama i problemima s kojima se djeca u cijelom svijetu susreću na različite načine i na različitim razinama (Zarzycka, 2016: 29). No, u nastojanjima ostvarenja navedenoga, nerijetko oni koji su u središtu humanitarne akcije i kome je pomoć na bilo kojoj razini potrebna što je paradoks, ostaju u sjeni.

Unatoč dobrim namjerama i pozitivnim emocijama koje se javljaju već pri samom spomenu humanitarne akcije kao kanala kroz koji će javnost putem medija moći pomoći nekome tko je u potrebi, ne postoji jasno određen okvir koji moraju slijediti svi inicijatori, odnosno pokretači neke humanitarne akcije. Upravo u tom području svi inicijatori, bilo da je riječ o jednoj osobi, skupini pojedinaca ili udruzi, trebali bi, uz pozitivne zacrtane ciljeve i nagon za pomaganjem, u svakom trenutku provođenja određene humanitarne akcije slijediti osnovna načela kojima će zaštititi upravo one kojima najviše žele pomoći. Čak i ako su takve smjernice nepostojeće na službenoj razini, mediji bi trebali biti ti koji će svojim profesionalnim izvještavanjem na ispravan način javnosti predstaviti neku humanitarnu akciju. Vođeni dobrim namjerama i prikupljanjem što više sredstava, neki pokretači huma- 
nitarnih akcija otkrivaju što više podataka o osobi ili osobama u potrebi, nadajući se da će baš takvim pristupom privući velik interes javnosti i ostvariti najveću pomoć.

Budući da je vizualnost snažan element u medijskom izvještavanju, fotografije djece sveprisutne su u humanitarnim akcijama te se smatraju svojevrsnim okidačima javnosti za pomoć, i to iz nekoliko razloga: prije svega, potiču empatiju javnosti više od teksta te privlače veći interes javnosti zbog izražene ranjivosti nego da je na fotografiji neki objekt, zbog čega su fotografije djece nerijetko najuspješniji alat uvjeravanja humanitarnih akcija (Zarzycka, 2016: 29). Vizualnost, odnosno vizualni narativ koji je sveprisutna i svojevrsna okosnica humanitarnih akcija može bitno utjecati na recepciju tako prezentiranog sadržaja kod publike. Naime, mediji kroz svoje izvještavanje o humanitarnim akcijama vrlo često koriste fotografije od kojih tvore određenu cjelinu koja potom kod javnosti konstruira stvarnost o određenom slučaju. U tom se kontekstu vizualni narativi definiraju i percipiraju kao nimalo statični, već kao izrazito dinamični komunikacijski procesi, ponajviše zbog snažnog utjecaja na konstruiranje stvarnosti (Gillespie 2006 prema Stević i Car, 2017: 26) i prezentiranje osobe ili humanitarne akcije u cijelosti publici.

O takvim je temama važno govoriti kako u društvenom životu tako i u znanstvenoistraživačkom radu prije svega zato što u Hrvatskoj gotovo pa i ne postoje radovi o djeci i zaštiti njihovih prava u humanitarnim akcijama. Važnost je i veća jer je riječ baš o djeci, najosjetljivijoj skupini primatelja medijskih sadržaja, a pogotovo kada su u potrebi i kada im je potrebna najviša moguća razina zaštite njihovih prava, posebice prava na privatnost. Koncept humanitarnih akcija često se idealizira upravo zbog prije navedene dobre namjere, plemenitoga cilja i pomoći nekome tko je u potrebi.

Idealizacija se u tom kontekstu odnosi i na samu retoriku i komunikacijske strategije humanitarnih akcija. Ona uključuje i određene komunikacijske stereotipe, poput poistovjećivanja pojmova plemenitosti, ljudskosti i emotivnosti sa sudjelovanjem u akciji, odnosno pomoći upravo toj akciji i toj osobi ili skupini osoba koje su u potrebi. Također, kroz takvu retoriku pokretači neke humanitarne akcije ističu moralnu obvezu društva za pomoć onima kojima je to potrebno i za koje je to organizirano (Nolan i Mikami, 2013: 55). Takvo poistovjećivanje i svojevrsno pozivanje društva, pri čemu se koristi navedena retorika, često je i u komunikaciji kroz humanitarne akcije koje su namijenjene djeci. Dakako da su svi spomenuti pojmovi pozitivni, no ne bi se trebali koristiti kao temeljni alat koji će uz izlaganje djetetove privatnosti i ogoljenja intime izazvati krajnje emocije čitavoga društva, primjerice emocije šoka ili ekstremne tuge, te rezultirati pomoći. Paradoks je da je pomoć potrebitima i povod i cilj humanitarnih akcija, ali je ključan način na koji se one provode, od samog pokretanja do postizanja cilja. Uspješnost svake humanitarne akcije mjerljiva je pristupom i načinom zaštite onih kojima je namijenjena, opet s posebnim i izrazitim naglaskom na djecu. Komunikacijske strategije i vještine u humanitarnim akcijama trebale bi odražavati i podizati svijest o postojećoj problematici i načinima na koje se može pomoći, a sve s ciljem održavanja temeljnih etičkih načela koja će s jedne strane otvarati važna društvena pitanja vezana uz djecu koja su u središtu humanitarne akcije, a s druge strane svojim izvještavanjem i prezentiranjem djeteta u humanitarnoj akciji pokazati profesionalnost, etičnost i zaštitu djeteta koje je u potrebi (Nolan i Mikami, 2013: 55-56). 
Također, još jedan pojam koji se veže uz način prikazivanja humanitarnih akcija u medijima jest pojam spektakla i on se češće vezuje uz zapadnu kulturu nego bilo koju drugu, a posebice kada je riječ o zemljama u razvoju, poput afričkih, o kojima će biti riječi u idućem poglavlju rada. Naime, kada je riječ o bilo kojoj humanitarnoj akciji, pa tako i onoj namijenjenoj djeci, ona se, ovisno o razmjerima i teritoriju koji zahvaća, pretvara u medijski spektakl popraćen senzacionalističkim izvještavanjem u središtu kojeg su oni kojima su akcije i namijenjene (Holzer i Warren, 2015: 485). Takvo izvještavanje u cijelosti je neusklađeno s temeljnim novinarskim postulatima, a posebice ukoliko je riječ o djeci, s obzirom na to da spektakl, senzacionalizam i zaštita djece nikako ne smiju biti istovremeno prisutni u medijskom izvještavanju. $U$ kontekstu humanitarnih akcija pojavio se i pojam humanitarni spektakl koji je definiran kao javna predstava ili prikazivanje te ogoljivanje osobe ili skupine osoba kojoj je akcija namijenjena, a sve se opravdava ciljem pomoći koja, postignuta na takav način, dovodi do humanitarne krize, što je također pojam uveden zbog spomenutih radnji (Holzer i Warren, 2015: 486).

Prije spomenuti nizozemski komunikolog Cees J. Hamelink, koji se bavio etičkom odgovornošću publike, tako navodi i da je u dobu globalizacije medija nužno uvesti takozvanu humanitarnu agendu koju će medijski djelatnici i mediji općenito slijediti, a koja će prevenirati i smanjiti sve nepovoljne utjecaje neprofesionalnog izvještavanja u tom području te kojoj je glavni cilj zaštita djece i dječjih prava (Hamelink, 2002: 16). Takva humanitarna agenda odnosi se ponajprije na medijske konglomerate čija bi se moć bolje regulirala i na nacionalnoj i na globalnoj razini, a koja bi istovremeno štitila medijske djelatnike koji sudjeluju u proizvodnji medijskih sadržaja. Drugo načelo humanitarne agende odnosi se na oglašivače koji ne bi bili prisutni u svim medijskim sadržajima s ciljem profita, već bi se njihova prisutnost filtrirala i selektirala, posebice kada je riječ o djeci u potrebi, odnosno djeci kao glavnim akterima određene humanitarne akcije. I posljednje, treće načelo Hamelinkove humanitarne agende vezano je uz zaštitu intelektualnog vlasništva i ono štiti čitavo društvo, a ponajviše djecu, od bilo kakvog oblika komercijalnog iskorištavanja te poziva čitavo građanstvo i primatelje medijskih sadržaja, kao i na same sudionike humanitarne akcije, na odgovornost (Hamelink, 2002: 40-41).

\section{PRIKAZ DJECE I DJEČJIH PRAVA U HUMANITARNIM AKCIJAMA NAMIJENJENIMA DJECI IZ AFRIČKIH DRŽAVA}

Jedna od posebno osjetljivih skupina djece koja su često u središtu humanitarnih akcija jesu djeca iz afričkih država, i to najčešće ona bez odgovarajuće roditeljske skrbi koja su smještena u dječje domove. Takve humanitarne akcije pokreću pojedinci, ali ponajviše brojne nevladine udruge (engl. NGO), no medijsko izvještavanje o njihovim humanitarnim akcijama nerijetko može biti uvjetovano vlašću određene države pa su tako neke humanitarne akcije kontinuirano u medijima, dok druge ostaju u sjeni (Frangonikolopoulos, 2005: 55). Često se događa da djeca ni u takvim slučajevima nisu u središtu humanitarne akcije koja se pokrenula samo i isključivo radi njihove dobrobiti. Također, još jedan od čimbenika zašto određeni humanitarni projekti ostanu u sjeni jest i nedovoljna povezanost $\mathrm{s}$ medijima kao posrednicima između djece u potrebi, njihovih predstavnika koji su u službi 
organizatora humanitarne akcije i javnosti koju treba potaknuti na pomoć (Frangonikolopoulos, 2005: 56). U porastu je i trend uključivanja većih tvrtki iz zapadnih zemalja u humanitarne akcije za afričku djecu, no i u takvim, iako neosporno plemenitim i korisnim namjerama i ciljevima, djeca nerijetko služe kao sredstvo promocije upravo određene tvrtke te su humanitarne akcije postale i dio marketinške te oglašivačke industrije (Höijer, 2004: 514).

Kada izvještavaju o humanitarnim akcijama, mediji se nerijetko vode već postojećim, stereotipnim portretiranjem afričke djece u potrebi te ih, unutar humanitarnih akcija, i dalje prikazuju bez dublje analize i promjene pristupa toj tematici (Lobb i Mock, 2007: 424). Shodno tome, njihovo izvještavanje, iako prvotno može biti dobronamjerno, nikako nije u cijelosti objektivno te se kosi s temeljnim etičkim načelima novinarske profesije, posebice u području zaštite djece i njihovih temeljnih prava. S druge strane, svi pokretači i provoditelji humanitarne akcije namijenjene djeci trebaju od početka do kraja akcije ostati u ulozi voditelja akcije, a medije koristiti kao alat između njih i javnosti koju žele potaknuti na djelovanje. No, zbog tehnološki visokorazvijene zapadne kulture, afričke zemlje i za njih ili u njima organizirane humanitarne akcije za djecu često prihvaćaju sve uvjete medija koji odluče izvještavati o njima, vođeni željom da pomognu djeci koja su u potrebi. Upravo u takvim situacijama, a vođeni medijskom etikom, medijski djelatnici trebali bi prepoznati i djelovati u skladu s načelima svoje profesije te izvijestiti o određenoj akciji štiteći djecu, a posebice njihov identitet, intimu i pravo na privatnost. Zapadne zemlje često Afriku generaliziraju, bez obzira na stanje u pojedinim državama, pa se tako generaliziraju i stereotipno prikazuju određeni pojmovi vezani i uz afričku djecu. Neki od najčešćih jesu bolest HIV-a, malarija, glad, siromaštvo, siročad ili sirotišta, neredi i sukobi i sl. (Gillens, 1996; Fluke i sur., 2003; Mtwana i Bird, 2006; Hobson, 2008; Hall i Smith, 2012).

Upravo bi mediji mogli i trebali postati odgovorni akteri u procesu sprječavanja generalizacije i stvaranja stereotipa te odgovornim i profesionalnim izvještavanjem o humanitarnim akcijama i projektima namijenjenima djeci iz afričkih država promijeniti stav javnosti. Dosljednošću i ujednačenošću te barem približno podjednakom zastupljenošću humanitarnih akcija za djecu u Africi moguće je spriječiti generaliziranje i poistovjećivanje djece čitavog jednog kontinenta s nekoliko stereotipnih i nerijetko s nekoliko stereotipnih i nerijetko pogrešnih slika i pojmova.

Pri izvještavanju o humanitarnim akcijama namijenjenima djeci iz afričkih zemalja javlja se i fenomen takozvane kultivacije humanitarne empatije kojoj je s jedne strane cilj da pomogne i umanji poteškoće koje djeca u potrebi imaju, no s druge strane nerijetko se događa da se neko dijete ili skupina djece prikazuju kao žrtve u nepovoljnim prilikama na koje djeca, dakako, nisu mogla niti mogu utjecati. U takvim se slučajevima humanitarne akcije i izvještavanja o njima koriste prikrivenim diskursima koji često rezultiraju univerzalnim obilježjima djetinjstva i generaliziranjem sve djece na način kao i, slijedom navedenoga, generalizacijom svih njihovih potreba, iako se one ne mogu i ne smiju poistovjećivati i gledati kao cjelina već svakom slučaju treba posvetiti dostatan medijski prostor i svakome od njih pristupiti na prikladan i njima svojstven način (Schultheis, 2008: 35). 


\section{ODGOJ ZA MEDIJE KAO PREDUVJET ODGOVORNOM PRISTUPU I VRJEDNOVANJU HUMANITARNIH AKCIJA}

Odgoj za medije postao je odgoj za 21. stoljeće. Zbog količine medijskih sadržaja kojima je javnost svakodnevno izložena nužno je odgajati za medije i kritički vrednovati medijske sadržaje, a u kontekstu teme ovoga rada posebice humanitarne akcije namijenjene djeci. Medijska pismenost sve korisnike osposobljava za osnovne vještine koje su potrebne za razumijevanje medija. $U$ te se vještine ubrajaju: cjelovita analiza medijskih sadržaja, kritički odmak i promišljanje o sadržajima, razumijevanje konteksta unutar kojega su medijski sadržaji nastali, interpretacija vrijednosti koje izvor medijske poruke promiče u sadržaju, sposobnost odabira kvalitetnih medijskih sadržaja te samostalno stvaranje i daljnja reprodukcija medijskih sadržaja (UNESCO, 1999 prema Gallardo-Echenique i sur., 2015: 6). UNESCO u svom dokumentu o okvirima, preduvjetima i spremnosti zemalja na uvođenje medijske pismenosti (2013) navodi da medijska pismenost građanima omogućava pristup sadržajima, njihovo preuzimanje i razumijevanje, vrednovanje i korištenje, a tek onda i produciranje te dijeljenje takvih sadržaja odgovornim i pouzdanim kanalima kako bi cjelokupno građanstvo moglo sudjelovati u osobnim, ali i društvenim aktivnostima (Grizzle i sur., 2014: 13). Osim navedenoga, uz pojam medijske pismenosti navodi se i pet ključnih vještina u koje se ubrajaju ove vještine odgovornost pri odabiru sadržaja i pristupu informacijama, analiza medijskih poruka, kao i njihovih autora i glavnih ciljeva, stvaranje sadržaja uz korištenje digitalnih kompetencija i audiovizualne opreme, stvaranje mišljenja i stavova o nečijim medijsko-komunikacijskim kompetencijama i usklađenost s temeljnim etičkim postulatima te samostalno preuzimanje inicijative za dijeljenje znanja i informacija u svojoj okolini (Hobbs, 2010 prema Hobbs, 2016: 4). U literaturi se uz medijsku pismenost spominju medijski odgoj, medijska kultura, medijsko obrazovanje te medijska pedagogija, ali i srodne „pismenosti”, poput emocionalne, digitalne, informatičke i informacijske. Također, sve navedene pismenosti i njihova terminologija u literaturi mogu biti i sastavni dio nekih nad-pojmova, a najkorišteniji od njih je transpismenost koja obuhvaća i sposobnost primanja svih vrsta medijskih sadržaja i vještine za njihovo korištenje, a koje uključuje njihovo razumijevanje i alate, ali istovremeno i sposobnost multimedijskog pretraživanja (pretraživanja putem različitih platformi i uz uporabu različitih dostupnih alata), pristupa informacijama i sadržajima, kritičkog vrednovanja informacija i sadržaja i samostalne proizvodnje ili stvaranja kvalitetnog sadržaja (Frau-Meigs, 2012: 15-16).

Kako bi svaki pojedinac bio osposobljen za korištenje medija i medijskih sadržaja, potrebna su mu tri takozvana „bloka” za nadogradnju razumijevanja medija. Tako William James Potter (2016: 17-24), ključni autor iz područja medijske pismenosti i autor spomenutih blokova, smatra da je prvi od njih na osobnoj razini pa ga zato i naziva "osobnim lokusom" (engl. personal locus), u koji ubraja mentalnu snagu, osobne ciljeve i motivaciju. Kroz osobni lokus trebaju se filtrirati sve informacije koje mediji plasiraju i kojima korisnici pristupaju te ih preuzimaju. Što je korisnik medijskih sadržaja svjesniji svojih ciljeva i mogućnosti koje želi dobiti od medija to su njegovi filteri informacija jasniji, konkretniji i učinkovitiji. S druge strane, kada je osobna motivacija i mentalna energija za razumijevanje medijskih sadržaja niska, tada se povećava vjerojatnost da će korisnik pasti pod utjecaj medijske kontrole i nefiltriranog oblikovanja svojih mišljenja, stavova i vrijednosti. Stoga 
su veća svjesnost i ulaganje u razvoj osobnog lokusa preduvjet razvoja medijskih kompetencija i sposobnosti pri razumijevanju i analizi medijskih poruka. Drugi se blok odnosi na „strukture znanja” (engl. knowledge structures) koje organiziraju sve naučeno vezano uz same početke stvaranja medijskog sadržaja pa do krajnje poruke koja se plasira putem različitih medijskih kanala. Organizacija znanja dugotrajan je proces koji gotovo u cijelosti ovisi o preciznosti i volji pojedinca. Informacije koje se pretvaraju u znanje ne smiju biti samo velike nakupine činjenica, već smislene cjeline od kojih se sastoji znanje o medijima u najširem kontekstu. Pravilno organizirane strukture znanja s vremenom stvaraju obrasce prema kojima korisnici mogu pouzdano i samostalno pronaći sve informacije i sadržaje koji su im potrebni. Naposljetku, u treći blok spadaju „vještine” (engl. skills) kojima se korisnik služi kao alatom za odabir informacija, njihovu selekciju i pohranjivanje u prethodno navedene strukture znanja. Naime, bez vještina nemoguće je dobiti sposobnost analize i kritičkog sagledavanja medijskih sadržaja. Temeljnim vještinama medijske pismenosti Potter smatra analizu, evaluaciju, grupiranje, indukciju, dedukciju, sintezu i sažimanje informacija. Takvim redoslijedom i usvajanjem svake od navedenih sedam vještina korisnik je u potpunosti medijski pismen i osposobljen za svakodnevno korištenje medija i medijskih sadržaja (Potter, 2016: 17-24).

Svaka od sedam spomenutih vještina ima svoje mjesto i značenje u procesu medijskog opismenjavanja. Potter je pojasnio svaku od vještina definicijama navedenima u nastavku. Analiza (1) podrazumijeva rastavljanje informacije na smislene dijelove i razumijevanje svakoga od njih kao dio jedne cjeline, odnosno medijske poruke. Evaluacija (2) uključuje procjenu i vrednovanje informacija kao elemenata medijske poruke. Potom se grupiranjem (3) određuje poveznica i sličnost između određenih elemenata informacije, kao i razlike s drugim elementima. Indukcija (4) podrazumijeva određivanje obrasca unutar pojedinačnih elemenata informacije te uopćavanje takvih elemenata u širu cjelinu, odnosno medijsku poruku. Dedukcija (5), s druge strane, koristi uopćena obilježja za pojašnjavanje i razumijevanje pojedinačnih elemenata kao dijelova cjeline. Sintezom (6) se elementi povezuju u nove strukture informacija i poruka, dok se naposljetku sažimanjem (7) stvaraju i dobivaju jasni, smisleni i točni ciljevi i vrijednost informacija i cjelokupne medijske poruke koja je došla do korisnika, odnosno primatelja (Potter, 2016: 17).

Prema prvom nacionalnom izvješću o medijskoj pismenosti u Hrvatskoj za medijsku pismenost ne postoji jasno definirana strategija prema kojoj bi se ona sustavno i cjelovito provodila u hrvatskom obrazovnom sustavu, što ponajviše pokazuje podatak da je i sam pojam medijske pismenosti spomenut tek prije četiri godine unutar dokumenta "Strategija obrazovanja, znanosti i tehnologije" (Kanižaj i Car, 2015: 20). Odgoj za medije je sveobuhvatan koncept koji se temelji na četiri elementa, a to su: pristup medijskim sadržajima, potom njihova analiza, kritičko vrednovanje i proizvodnja medijskih sadržaja te komuniciranje sadržaja u širu javnost, a sve s ciljem odgovornijeg i aktivnijeg sudjelovanja građana u za njih važnim društvenim procesima (Aufderheide, 1993: 33).

UNESCO je 2013. godine počeo koristiti i termin medijsko-informacijska pismenost, definirajući je kao niz vještina kroz koje građani pristupaju, razumiju, vrednuju, koriste i dijele medijske i informacijske sadržaje, pri čemu se etično i kritički služe alatima zbog 
čega će naposljetku i moći biti aktivni i odgovorni građani (UNESCO, 2013: 29), o čemu je pisala i prethodno spomenuta autorica Patricia Aufderheide. Odgoj za medije u kontekstu razumijevanja medijskog izvještavanja, važnosti zaštite dječjih prava i razumijevanja humanitarnih akcija ključna je kompetencija za javnost na svim razinama, od najmlađih do najstarijih građana, odnosno namijenjena je svima koji na bilo koji način koriste medije, sudjeluju u proizvodnji medijskih sadržaja ili su okruženi medijima.

Medijska pismenost, osim sposobnosti analize, razumijevanja i proizvodnje medijskih sadržaja, podrazumijeva i puno širi spektar sposobnosti koje se manifestiraju kroz razumijevanje i važnost sveukupne kritičke osviještenosti građanstva o sadržajima, kontekstu i promjenama unutar medijskih struktura, kao i kroz osnaživanje korisnika za pravovremeno i ciljano informiranje i shvaćanje medijske industrije i njezinih „proizvoda”, odnosno svih oblika sadržaja (Hobbs, 2016: 9). Jedan od najvažnijih rezultata usvojene i u praksi provedene medijske pismenosti jest sposobnost samostalnog kritičkog promišljanja o medijima i njihovim sadržajima ponajviše zato što mediji prezentirajući tek jedan dio stvarnosti iz odabranog kuta te namjerno izostavljajući pojedinosti i osobe, odnosno koristeći raspoložive metode manipulacije sadržaja, uzimajući tek jedan dio stvarnosti, izvrćući drugi i izmišljajući treći, oblikuju potpuno novu stvarnost. Zbog te, ali i brojnih drugih pojava poput nasilja, senzacionalizma i manipulacija u medijima, medijska pismenost ključan je i povrh svega odgojno-obrazovni pojam (Uldrijan, 2011: 185-186).

U području razumijevanja, ali i pokretanja humanitarnih akcija te općenito u pristupu samim akcijama nužna je visoka razina medijske pismenosti svih aktera. Odgoj za medije osnažuje istovremeno i medijske djelatnike koji prenose određenu humanitarnu akciju javnosti, potom same aktere, a ponajviše djecu i njihove predstavnike koji su u potrebi te i samu publiku, odnosno javnost, koju se nastoji potaknuti na pomoć (Torrent, 2017: 283). Odgoj za medije ima najučinkovitiji utjecaj kada istovremeno i kontinuirano obuhvaća sve aktere, počevši od samih medija i medijskih djelatnika, medijskih vlasnika, primatelja medijskih sadržaja, odnosno javnosti, djece i svih koji su uključeni u proces medijskog izvještavanja o određenoj temi, a u ovome slučaju o humanitarnim akcijama.

\section{SMJERNICE ZA MEDIJSKO IZVJEŠTAVANJE O HUMANITARNIM AKCIJAMA NAMIJENJENIMA DJECI}

Zbog snažnog utjecaja medijske reprezentacije humanitarnih akcija u čijem su središtu djeca te zbog nedovoljne zaštite njihovih temeljnih prava i sprječavanja konstruiranja nedovoljno profesionalne stvarnosti i samog pristupa kako novinara tako i publike, pri svakoj medijskoj reprezentaciji humanitarne akcije namijenjene pomoći djeci ili skupini djece nužno je slijediti prije svega temeljna etička načela novinarske profesije, potom biti upućen u sve dokumente i smjernice za profesionalno izvještavanje o djeci, sustavno se educirati kako u području odgoja za medije tako i u području humanitarnih akcija te uvijek pronalaziti i u svom izvještavanju prikazati profesionalnu ravnotežu između zaštite dječjih prava i postizanja krajnjeg cilja humanitarne akcije, a to je pomoć djetetu ili djeci u po- 
trebi. U nastavku rada navedene su smjernice za medijsko izvještavanje o humanitarnim akcijama, ali i za publiku koja putem medija prati određene humanitarne akcije.

(1) Poštivati i u izvještavanju štititi temeljna dječja prava i interese tijekom čitavoga trajanja humanitarne akcije te izvještavanje uskladiti s ključnim dokumentima vezanima uz zaštitu dječjih prava.

(2) Pri apelima na javnost ne koristiti detalje iz djetetove intime te ga ne izlagati nepotrebno pogledima javnosti zbog dugotrajnih i etiketirajućih posljedica koje takav pristup u humanitarnoj akciji može imati i na dijete i na javnost.

(3) U izvještavanju izbjegavati generalizaciju sve djece na temelju jednog slučaja na bilo kojoj razini - nacionalnoj, vjerskoj, rasnoj, teritorijalnoj ili bilo kojoj drugoj.

(4) Ne koristiti djetetove privatne fotografije kao način za uvjeravanje javnosti (primjerice, učestalo korištenje fotografija djeteta spojenoga na aparate u bolničkome krevetu samo kako bi se potakla empatija javnosti za bolesno dijete).

(5) Pri izvještavanju osvještavati javnost o određenom problemu koristeći neki izdvojeni slučaj kao primjer, a ne kao središte izvještavanja, ogoljujući intimu i narušavajući temeljna prava djeteta (primjerice, pri organiziranju humanitarne akcije namijenjene pomoći dječjim domovima ne objavljivati obiteljske i ostale privatne prilike djeteta).

(6) Pri izvještavanju o humanitarnim akcijama za pomoć djeci iz afričkih zemalja ili bilo kojih drugih zemalja u razvoju ne koristiti stereotipe, već profesionalnim izvještavanjem i prilagođenom retorikom izbjegavati senzacionalistički pristup takvim temama. (7) Profesionalnim i etičnim izvještavanjem uvažavati i uključivati sve aktere humanitarne akcije poštujući njihova temeljna ljudska prava, bilo da je riječ o pokretačima akcije, osobama bliskima akterima u potrebi, samim akterima, a posebice djeci kojima je potrebna pomoć te naposljetku i čitavoj javnosti.

(8) Bez obzira na prilike djeteta ili djece koja su u potrebi ne etiketirati ih i definirati isključivo kroz nepriliku zbog koje su došli u središte neke humanitarne akcije.

(9) Sustavno odgajati za medije cjelokupnu javnost, posebice kada je riječ o izvještavanju o humanitarnim akcijama namijenjenima djeci, kojima sam sadržaj automatski daje pozitivan prizvuk u javnosti.

(10) Sustavnom edukacijom medijskih djelatnika i publike mijenjati postojeće stereotipne paradigme o određenim dijelovima svijeta i djeci koja su u potrebi te poticati građanstvo na savjesno pristupanje svakom pojedincu ili skupini koja je u središtu neke humanitarne akcije.

\section{ZAKLJUČAK}

Slijedom svega istaknutoga u ovome preglednom radu nužno je vratiti se na temeljne etičke i medijske postulate profesionalnoga izvještavanja, na odgovornost publike, zaštitu dječjih prava te na profesionalni pristup izvještavanju o humanitarnim akcijama namijenjenima djeci, s posebnim naglaskom na afričke zemlje, kao i na nužnost medijskoga odgoja kao prevencije i pomoći medijskim djelatnicima s ciljem što je moguće veće objektivnosti, izbjegavanja stereotipnog izvještavanja o humanitarnim akcijama te 
izgradnje profesionalnoga umijeća između zaštite dječjih prava u humanitarnim akcijama, senzibilizacije javnosti te pomoći djeci u potrebi. Takva vrsta izvještavanja svojevrsni je izazov za cijelu novinarsku profesiju, ali i komunikologiju kao znanost, zbog niza slučajeva nedovoljno profesionalnoga pristupa takvim temama, unatoč brojnim međunarodnim udrugama i institucijama te njihovim postojećim smjernicama za takav oblik izvještavanja. Zbog toga što su djeca najosjetljivija skupina društva te što se javnost, odnosno različite medijske publike, nastoji potaknuti na pomoć, nužna je stalna edukacija, usavršavanje medijskih profesionalaca u skladu s postojećim globalnim trendovima, neprestani razvoj medijskih tehnologija i pristupa te informiranje i obrazovanje same javnosti o pogledu i doživljavanju afričkih zemalja, odnosno djece u potrebi u očima zapadnih zemalja. Upravo je zbog toga nužno da se izvještavanje o humanitarnim akcijama namijenjenima djeci dovede na najvišu moguću profesionalnu razinu te da se preuzme odgovornost medijatora između zaštite dječjih prava i informiranja javnosti o potrebama djece, kao i senzibilizacije javnosti te poticanja na pomoć. Unatoč brojnim postojećim smjernicama i inicijativama, kako na institucionaliziranoj tako i na razini nevladinih organizacija i volonterskih udruga, u 21. stoljeću upravo je afrički kontinent, s posebnim naglaskom na djecu u potrebi, izložen sveopćoj javnosti na način koji nije uvijek usklađen s postojećom regulativom i profesionalnim načelima izvještavanja. Nedovoljno ozbiljan i profesionalan pristup često vodi u stvaranje stereotipa, generalizaciju i etiketiranje djece, s opravdanjem da cilj dopušta svako sredstvo, pa tako i potpuno iznošenje intime i obiteljskih prilika, koje, posebice u današnjem dobu, gotovo pa neizbrisivo i nepovratno obilježavaju djecu i u sjenu stavljaju njihova temeljna prava. Zbog svega navedenoga nužno je stalno usavršavanje, kako u praksi tako i u znanosti vezanoj uz ovakve i slične teme. Odgoj za medije jedno je od dokazano učinkovitih rješenja koje djelovanjem i postojanjem na svim razinama društva i medijskih publika, kao i djelatnika, može učiniti velike promjene i pravovremenim pristupom i prihvaćanjem promijeniti način pristupa i slijeđenja temeljnih etičkih i profesionalnih načela, a sve u svrhu zaštite djeteta i njegovih prava.

\section{Literatura}

>Aronson, Elliot; Wilson, Tim D. i Akert, Robin M. (2005) Socijalna psihologija. Zagreb: MATE, d.o.o. >Aufderheide, Patricia (1993) Media Literacy: A Report of the National Leadership Conference on Media Literacy. Queenstown, Maryland: The Aspen Institute Wye Center.

>Calvert, Sandra L. i Wilson, Barbara J. (ur.) (2009) The Handbook of Children, Media and

Development. John Wiley \& Sons. DOI: 10.1002/9781444302752.

>Ciboci, Lana; Jakopović, Hrvoje; Opačak, Suzana; Raguž, Anja i Skelin, Petra (2011) Djeca u dnevnim novinama: analiza izvještavanja o djeci u 2010., str. 103-166, u: Ciboci, Lana; Kanižaj, Igor i Labaš, Danijel (ur.) Djeca medija: od marginalizacije do senzacije. Zagreb: Matica hrvatska.

>Ciboci, Lana i Osmančević, Leali (2017) Percepcija učenika osmih razreda o prikazu djece i njihovih prava u hrvatskim medijima, str. 91-104, u: Car, Viktorija i Matović, Marijana (ur.) Mediji, novinarstvo i ljudska prava. Zagreb: Fakultet političkih znanosti i Hanns-Seidel-Stiftung.

>Fiske, John (2010) Introduction to Communication Studies. London: Routledge. DOI: $10.4324 / 9780203837382$.

>Flego, Maja (2011) Zaštita prava djece u medijima, str. 65-83, u: Ciboci, Lana; Kanižaj, Igor i Labaš, Danijel (ur.) Djeca medija: od marginalizacije do senzacije. Zagreb: Matica hrvatska. 
>Fluke, John D.; Yuan, Ying Ying T.; Hedderson, John i Curtis, Patrick A. (2003) Disproportionate Representation of Race and Ethnicity in Child Maltreatment: Investigation and Victimization. Children and Youth Services Review 25 (5-6): 359-373. DOI: 10.1016/s0190-7409(03)00026-4. $>$ Frangonikolopoulos, Christos A. (2005) Non-governmental Organisations and Humanitarian Action: The Need for a Viable Change of Praxis and Ethos. Global Society 19 (1): 49-72. DOI: 1360082042000316040.

>Frau-Meigs, Divina (2012) Transliteracy as the New Research Horizon for Media and Information Literacy. Medijske studije 3 (6): 14-27.

>Gallardo-Echenique, Eliana E.; Marqués-Molías, Luis; Bullen, Mark i Strijbos, Jan-Willem (2015). Let's Talk about Digital Learners in the Digital Era. The International Review of Research in Open and Distributed Learning 16 (3). DOI: 10.19173/irrodl.v16i3.2196.

$>$ Gilens, Martin (1996) Race and Poverty in America Public Misperceptions and the American News Media. Public Opinion Quarterly 60 (4): 515-541. DOI: 10.1086/297771.

>Grizzle, Alton; Moore, Penny; Dezuanni, Michael; Asthana, Sanjay; Wilson, Carolyn; Banda, Fackson i Onumah, Chido (2014) Media and Information Literacy: Policy and Strategy Guidelines. Pariz: UNESCO.

>Hall, Horace R. i Smith, Eleshia L. (2012) "This Is Not Reality... It's Only TV": African American Girls Respond to Media (Mis)Representations. The New Educator 8 (3): 222-242. DOI:

10.1080/1547688x.2012.697014.

>Hamelink, Cees J. (2002) Media Globalisation: Consequences for the Rights of Children, str. 31-41, u: Cecilia von Feilitzen i Ulla Carlsson (ur.) Children, Young People and Media Globalisation. Göteborg: The UNESCO International Clearing house on Children, Youth and Media, Nordicom i Göteborg University.

>Hilhorst, Dorothea i Jansen, Bram J. (2012) Constructing Rights and Wrongs in Humanitarian Action: Contributions from a Sociology of Praxis. Sociology 46 (5): 891-905. DOI: $10.1177 / 0038038512452357$.

>Hobbs, Renee (2016) Exploring the Roots of Digital and Media Literacy through Personal Narrative. Philadelphia, Pennsylvania: Temple University Press.

>Hobson, Janell (2008) Digital Whiteness, Primitive Blackness: Racializing the "Digital Divide" in Film and New Media. Feminist Media Studies 8 (2): 111-126. DOI: 10.1080/00220380801980467.

$>$ Höijer, Birgitta (2004) The Discourse of Global Compassion: The Audience and Media Reporting of Human Suffering. Media, Culture \& Society 26 (4): 513-531. DOI: 10.1177/0163443704044215.

$>$ Holzer, Elizabeth i Warren, Kamryn (2015) Humanitarian Spectacles from Below: A Study of Social Connections in Unsettled Contexts. Ethnography 16 (4): 482-502. DOI: 10.1177/1466138114562310. >Hromadžić, Hajrudin (2014) Medijska konstrukcija društvene zbilje. Zagreb: AGM.

>Kanižaj, Igor i Car, Viktorija (2015) Hrvatska: Nove prilike za sustavan pristup medijskoj pismenosti, str. 19-38, u: Car, Viktorija, Turčilo, Lejla, Matović Marijana (ur.) Medijska pismenost-preduvjet za odgovorne medije. Sarajevo: Fakultet političkih nauka.

$>$ Labaš, Danijel i Vizler, Ana (2005) Odgovornost primatelja u svjetlu medijske etike. Nova prisutnost 3 (2): 277-296.

>Lemish, Dafna (2015) Children and Media: A Global Perspective. John Wiley \& Sons.

>Lobb, Anno i Mock, Nancy (2007) Dialogue is Destiny: Managing the Message in Humanitarian Action. Prehospital and Disaster Medicine 22 (5): 423-428. DOI: 10.1017/s1049023x0000515x. $>$ Majstorović, Dunja (2017) Etički prijepori i vjerodostojnost dnevnih novina - analiza tekstova s naslovnica Jutarnjeg lista i Večernjeg lista. Medijske studije 1 (1-2): 55-64.

$>$ McQuail, Dennis (2010) McQuail's Mass Communication Theory. 6. izdanje. London: SAGE. >Minear, Larry; Scott, Colin i Weiss, Thomas G. (1996) The News Media, Civil War, and Humanitarian Action. Lynne Rienner Publishers.

>Mtwana, Nonceba i Bird, William (2006) Revealing Race: An analysis of the Coverage of Race and Xenophobia in the South African Print Media. Johannesburg: Media Monitoring Project. 
$>$ National Research Council (2003) Psychosocial Concepts in Humanitarian Work with Children: A Review of the Concepts and Related Literature. Maryanne Loughry and Carola Eyber. Roundtable on the Demography of Forced Migration, Committee on Population, Division of Behavioral and Social Sciences and Education and Program on Forced Migration and Health at the Joseph L. Mailman School of Public Health of Columbia University. Washington, DC: The National Academies Press. DOI: $10.17226 / 10698$.

>Nolan, David i Mikami, Akina (2013) 'The Things that We Have to Do': Ethics and Instrumentality in Humanitarian Communication. Global Media and Communication 9 (1): 53-70. DOI:

$10.1177 / 1742766512463040$.

>Oyero, Olusola (2010) Children: As "Invisible" and Voiceless as Ever in the Nigerian News Media. Estudos em Communicacão 2: 25-41.

>Potter, William James (2016) Media literacy. 8. Izdanje. SAGE Publications. DOI: 10.1093/ obo/9780199756841-0065.

$>$ Schultheis, Alexandra (2008) African Child Soldiers and Humanitarian Consumption. Peace Review 20 (1): 31-40. DOI: 10.1080/10402650701873700.

>Silverblatt, Art; Smith, Andrew; Miller, Don; Smith, Julie i Brown, Nikole (2014) Media Literacy: Keys to Interpreting Media Messages. 4. izdanje. Santa Barbara, California; Denver, Colorado i Oxford England: ABC-CLIO.

>Stević, Anja i Car, Viktorija (2017) Vizualno portretiranje izbjeglica i migranata - ikonske fotografije, u: Car, Viktorija i Matović, Marijana (ur.) Mediji, novinarstvo i ljudska prava. Zagreb: Fakultet političkih znanosti i Hanns-Seidel-Stiftung.

>Torrent, Jordi (2017) Plural+ Media Literacy, and Voices of the Young, u: Andersen, Robin i De Silva, Purnak L. (ur.) (2017) Routledge Companion to Media and Humanitarian Action. London: Routledge. DOI: 10.4324/9781315538129.

>Uldrijan, Ivan (2011) Zašto odgajati za medije? Mediji kao odgojitelji u doba odgojne krize, str. 173192 u: Labaš, Danijel (ur.) Komunikacija i mediji u krizi. Zagreb: Hrvatski studiji.

>UNESCO (2013) Global Media and Information Literacy Assessment Framework: Country Readiness and Competencies. http://unesdoc.unesco.org/images/0022/002246/224655e.pdf (11.03.2018.).

$>$ Vilović, Gordana (2007) Prava djeteta i mediji - etički aspekti, str. 31-35, u: Gabelica Šupljika, Maja (ur.) Pozitivni sadržaji za djecu i o djeci. Zagreb: Pravobraniteljica za djecu.

>Vlainić, Marta (2012) Kako hrvatske dnevne novine izvještavaju o djeci: analiza sadržaja Jutarnjeg i Večernjeg lista. Medijska istraživanja 18 (1): 33-59.

$>$ Weiss, Thomas (2018) Humanitarian Challenges and Intervention. New York: Routledge. DOI: $10.4324 / 9780429495182$.

>Zarzycka, Marta (2016) Save the Child: Photographed Faces and Affective Transactions in NGO Child Sponsoring Programs. European Journal of Women's Studies 23 (1): 28-42. DOI: $10.1177 / 1350506814568362$. 


\section{PROTECTION OF CHILDREN'S RIGHTS IN HUMANITARIAN ACTIONS WITH AN OVERVIEW OF AFRICAN COUNTRIES'}

\section{Leali Osmančević}

ABSTRACT The author writes about the role of the media in society, the importance of media ethics and media education, especially in the context of children and the protection of children's rights. Humanitarian actions aimed at children in need are a frequent topic in the media, but, paradoxically, children and their needs as well as their rights, especially the right to privacy and the right to expression of opinion, are marginalised. The media often appeal to the audience to take part in extending aid through humanitarian actions and by stimulating extreme emotions among members of the audience. It often occurs in such cases that a child, as the main subject of a humanitarian action, gets overly exposed, his/her intimacy thus being accessible to everyone. Such phenomena are often accounted for by the argument that anything being done in the public interest is justified. The aim of this paper is to outline the importance of protecting children as the most vulnerable group of society and children's rights in prosocial media content such as humanitarian actions. The paper also provides an overview of the status of reporting on humanitarian actions aimed to help children in African countries.

KEY WORDS

CHILDREN, MEDIA, CHILDREN'S RIGHTS, HUMANITARIAN ACTIONS, CHILDREN'S HOMES, MEDIA EDUCATION

Author's Note

Leali Osmančević :: Catholic University of Croatia, Zagreb, Croatia :: leali.osmancevic@unicath.hr

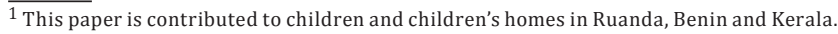

